\title{
Effects of single nucleotide polymorphism markers on the carcass and fattening traits in different pig populations
}

\author{
R. Bižienė ${ }^{1}$, K. Morkūnienè, R. Mišeikienè, N. Pečiulaitienè, N. Makštutienè and E. Šlyžius \\ Lithuanian University of Health Sciences, Kaunas, 44307, Lithuania
}

KEY WORDS: single nucleotide polymorphism, restriction fragment length polymorphism, growth hormone, leptin, myogenic factor 5 , pig breeds

Received: $\quad 13$ July 2017

Revised: $\quad 23$ May 2018

Accepted: 13 September 2018

${ }^{1}$ Corresponding author:

e-mail: renata.biziene@Ismuni.It

\begin{abstract}
The objective of this study was to investigate the effect of single nucleotide polymorphisms in 4 different genes: growth hormone $(G H)$, leptin $(L E P)$, growth hormone releasing hormone (GHRH) and myogenic factor 5 (MYF5) on fattening and carcass traits in pigs. The polymorphisms of the porcine genes and their relationships with performance traits were analysed in 143 unrelated pigs, belonging to 5 different breeds (Lithuanian White, old-type Lithuanian White, Large White, Landrace and Yorkshire) and 3 groups of crossbreeds (Large White $\times$ Landrace, Yorkshire $\times$ Large White, Yorkshire $\times$ Pietrain). It was found, that MYF5 polymorphism (Y17154.1: g2200G>C) influenced fattening traits with the highest daily weight gain stated in CC genotype. The most preferable LEP polymorphism (Taql) (U66254.1: g.1112G>A) was AG genotype with lower age to achieve $100 \mathrm{~kg}$ of body weight and average backfat thickness, and higher meatness and weight of ham. It was found that pigs with TT genotype in LEP polymorphism (Hinfl) (U66254.1: g.3469T>C) had better carcass properties in comparison to other genotypes. These pigs had also the highest meatness and the lowest average backfat thickness. The preferable GHRH polymorphism (JX435113.1: g.405A>C) genotype was CC with the highest daily weight gain. The most desirable TT genotype of LEP polymorphism (Hinfl) (U66254.1: g.3469T>C) was found with the highest frequency in Landrace breed. The highest frequency of the most desirable CC genotype of GHRH gene was found in Yorkshire pig breed. So, from all examined genes $L E P$ and GHRH genes polymorphisms seem to be the most preferable biomarkers of pig selection process.
\end{abstract}

\section{Introduction}

As consumers seek tastier, healthier, safer and more nutritious pork, the quality of the meat has been improved. The pork quality is influenced by many genetic and non-genetic factors, therefore many studies have been focused on revealing the genetic background and describing various genetic factors (Lee et al., 2014).

Pork is one of the most widely consumed meats in the world. For consumers meat tenderness, juici- ness, flavour, texture assessed by $\mathrm{pH}$, colour, intramuscular fat, moisture content, protein content, and sensory analysis are important parameters indicating product quality. Also, a number of candidate genes has been identified as potentially relevant to pork meat quality traits (Wang et al., 2012). Knowledge about structural variations in genes and proteins relevant for fat traits is essential to improve selection of breeding lines and preserve genetic variability in pig industry (Kim et al., 2009). 
Many genes influencing pig fattening characteristics and carcass traits is known. However, since high qualitative and quantitative indicators are influenced by a number of genes and gene groups, which are not always expressed in the same way, it is necessary to assess the effect of separate genes and aggregated genotypes in specific populations and breeds of pigs before introducing them into selection programmes (Chikuni et al., 1997; Grochowska et al., 1999; Curi et al., 2005).

Growth hormone (GH) is a 190-amino acid hormone which regulates growth, development and various metabolic activities. Particularly in pigs this gene controls growth and fat deposit (Song et al., 2003; $\mathrm{Li}$ et al., 2006). The growth hormone gene $(G H)$ is localized on chromosome pair 12 (in the p1.4 region) (Rejduch, 2008). Growth hormone releasing hormone (GHRH) stimulates the proliferation of pituitary somatotroph cells during their development and regulates their ability to synthetize and secrete $\mathrm{GH}$ (Pierzchała et al., 2003).

Skeletal muscle development is a highly regulated and complex process that directs myogenic precursor cells to differentiate into muscle fibres. Muscle regulatory factors (MRF) belong to a family of basic helix-loop-helix transcription factors that initiate the formation of muscle fibres and regulate the transcription of muscle-specific genes (Zhu et al., 2014). The MRF family consists of four factors: MYOD1 (MYF-3), MYF-5, myogenin and MRF4 (MYF-6), encoded by MYOD1 (MYF3), MYF5, MYOG and MRF4 (MYF6), respectively, known as the MYOD family genes (Urbański et al., 2006). The MYF5 gene is expressed in muscle cells during embryonic muscle development. This gene has been considered as a candidate gene for meat production and meat quality selection (te Pas et al., 1999).

Leptin gene ( $L E P)$, commonly known as obesity gene, is a key factor controlling carcass fat content and meat mass. The fat content of carcass is an important polygenic trait in pig breeding practices. Research studies indicate that leptin (LEP) and its receptor (LEPR) play an essential role in food intake and energy balance (Georgescu et al., 2014). Leptin is produced mainly by adipose tissue (adipocytes) but its expression is also stated in brain, heart, placenta, stomach wall and some neoplasms (StępienPoleszak et al., 2009). The $L E P$ was mapped on pig chromosome 18q13-q21. In swine this gene is composed of three exons and two introns (De Oliveira Peixoto et al., 2006).

It was found that introduction of certain varieties with specific single nucleotide polymorphism (SNP) into pig populations can increase their breeding value (Caraballo et al., 2018). So, the aim of this study was to investigate the association between $G H, G H R H$, $M Y F 5$ and $L E P$ gene polymorphisms and farm traits of pigs.

\section{Material and methods}

In total, 143 unrelated animals belonging to Lithuanian White (LiW; 47), old-type Lithuanian White (OLiW; 10), Large White (LW; 20), Landrace (L; 11), Yorkshire (Y; 14) and crossbreeds of Large White and Landrace (LW $\times \mathrm{L} ; 16)$, Yorkshire and Large White $(\mathrm{Y} \times \mathrm{LW} ; 14)$, Yorkshire and Pietrain $(\mathrm{Y} \times \mathrm{P} ; 11)$ were genotyped. The data of animal productivity were obtained from State Pig Breeding Station Information Centre (Radviliškis district, Lithuania), which controls productivity, fattening, slaughter and carcass evaluation of breeding pigs. Database of the following characteristics of pigs was formed:

- fattening characteristics - age at slaughter, days; time to reach $100 \mathrm{~kg}$ of body weight, days; daily weight gain, g; feed intake, $\mathrm{kg}$; feed conversion ratio (FCR), \%;

- carcass traits - warm carcass weight, kg; length of carcass, cm; length of bacon, cm; ham weight, $\mathrm{kg}$; backfat thickness at $6^{\text {th }}-7^{\text {th }}$ rib, mm; backfat thickness at the last lumbar vertebra; muscle depth, mm; carcass content, $\%$.

Carcass traits were evaluated using ultrasound scanner Piglog-105 (SFK Technology, Herlev, Denmark).

Hair root samples were taken into plastic bags with references. Analyses were done in Lithuanian University of Health Sciences, K. Janušauskas Laboratory of Genetic (Kaunas, Lithuania). DNA was extracted from hair roots using DTT $(1 \mathrm{M})$, Chelex 100, Proteinase K $(20 \mathrm{mg} / \mathrm{ml})$ chemicals (Thermo Fisher Scientific, Waltham, MA, USA). About 5 hair roots were cut and placed in a tube. A lysis mixture (DTT - $7.5 \mu$, Chelex $-200 \mu$, Proteinase $\mathrm{K}-10.7 \mu \mathrm{l})$ was prepared. The lysis mixture was added into tube with hair roots. The samples were incubated for $45 \mathrm{~min}$ at $56^{\circ} \mathrm{C}$. After incubation samples were heated at $94^{\circ} \mathrm{C}$ for $10 \mathrm{~min}$. The method of polymerase chain reaction (PCR) and restriction fragment length polymorphism (RFLP) was used to genotype GH, GHRH, LEP and MYF5 gene polymorphisms. PCR reactions were performed in $25 \mu \mathrm{l}$ of reaction mixture containing $1 \mathrm{U}$ Taq DNA Polymerase, $0.2 \mathrm{mM}$ dNTP (Thermo Fisher Scientific, Waltham, MA, USA) and $1 \mu \mathrm{M}$ of each primer pair (Table 1) using Applied Biosys- 
Table 1. Growth hormone (GH), growth hormone receptor (GHR), miogenic factor 5 (MYF5) and leptin (LEP) genes polymorphisms, oligonucleotide primers and reaction conditions

\begin{tabular}{|c|c|c|c|c|c|}
\hline Gene & $\begin{array}{l}\text { Sequence accession } \\
\text { number: polymorphism }\end{array}$ & $\begin{array}{l}\text { Restriction } \\
\text { enzyme }\end{array}$ & Primers ( $\mathrm{F}$ - forward; $\mathrm{R}$ - reverse) & $\begin{array}{l}\text { Annealing tempera- } \\
\text { ture, }{ }^{\circ} \mathrm{C}\end{array}$ & $\begin{array}{l}\text { Product length, } \\
\text { bp }\end{array}$ \\
\hline MYF5 & Y17154.1: g2200G>C & Hinfl & $\begin{array}{l}\text { F: 5'-CTCCGAATTAGTGTGGCTTC-3' } \\
\text { R: 5'-GTTCTTTCGGGACCAGACAGGCCTC-3' } \\
\text { te Pas et al. (1999) }\end{array}$ & 60 & 322 \\
\hline LEP & U66254.1: g.1112G>A & Taql & $\begin{array}{l}\text { F: 5'-CAACTCACCGTCGCTTTCTTGAT-3' } \\
\text { R: 5'-AGGGAAGCGGAGGAGCAAAG-3' } \\
\text { Jiang and Gibson (1999) }\end{array}$ & 61 & $\begin{array}{l}569 \\
437+132\end{array}$ \\
\hline LEP & U66254.1: g.3469T>C & Hinfl & $\begin{array}{l}\text { F: 5'-GAGCCAACATCTCTCTGGCTGAG-3' } \\
\text { R: 5'-GACTCCTGGAAGCTCAGGTTTCTT-3' } \\
\text { Jiang and Gibson (1999) }\end{array}$ & 61 & $\begin{array}{l}469 \\
347+118+4\end{array}$ \\
\hline $\mathrm{GHRH}$ & JX435113.1: g.405A>C & Alull & $\begin{array}{l}\text { F: 5'-GTAAGGATGC(C/T)(A/G)CTCTGGT-3' } \\
\text { R: 5'-TGCCTGCTCATGATGTCCTGGA-3' } \\
\text { Franco et al. (2005) }\end{array}$ & 60 & $\begin{array}{l}455 \\
230+100 / \\
250+100\end{array}$ \\
\hline $\mathrm{GH}$ & M17704.1: g.316G>A & Fokl & $\begin{array}{l}\text { F: 5'-TTATCCATTAGCACATGCCTGCCAG -3' } \\
\text { R: 5'-CTGGGGAGCTTACAAACTCCTT -3' } \\
\text { Knorr et al. (1997) }\end{array}$ & 59 & $\begin{array}{l}604 \\
345+259\end{array}$ \\
\hline
\end{tabular}

tems 2700 Thermal Cycler (Applied Biosystems, Foster City, CA, USA). The reaction conditions were: an initial denaturation step at $95^{\circ} \mathrm{C}$ for $2 \mathrm{~min}$; 35 cycles of denaturation at $94{ }^{\circ} \mathrm{C}$ for $30 \mathrm{~s}$, annealing for $45 \mathrm{~s}$ at temperature presented in Table 1 and elongation at $72{ }^{\circ} \mathrm{C}$ for $45 \mathrm{~s}$; and a final elongation step at $72{ }^{\circ} \mathrm{C}$ for $5 \mathrm{~min}$. After amplification $10 \mu \mathrm{l}$ of PCR product were digested with selected restriction enzyme (Table 1) according to producer recommendations (Thermo Fisher Scientific, Waltham, MA, USA). Visualization of the different genetic types was carried out by 3\% agarose gel electrophoresis. The ethidium bromide was added to agarose to a final concentration of $0.5 \mu \mathrm{g} / \mathrm{ml}$ (Thermo Fisher Scientific, Waltham, MA, USA). Fragment identification was performed in ultraviolet light, using MiniBIS Pro Video Documentation System (DNR Bio Imaging System, Neve Yamin, Israel).

\section{Statistical analyses}

Investigative gene allele and genotype frequencies in each pig breed and entire selective population were examined. Actual and expected heterozygosity in the examined loci was determined in each breed and entire group of animals as well as deviation from Hardy-Weinberg equilibrium law was determined with the help of R 2.1.0 package (http:// www.r-project.org/). Chi-square test and Student T-test were calculated for comparison between categorical variables. Results were considered statistically significant if $P<0.05$. The effect of genotypes on fattening and carcass characteristics was assessed by single factor analysis of variance (ANOVA).

\section{Results}

In a cross-section of pigs $G H, G H R H, M Y F 5$ and $L E P$ gene variants were investigated. Frequencies of different variations of $G H, G H R H, M Y F 5$ and $L E P$ genes were calculated in each examined breed (Table 2). For $L E P$ gene two polymorphic sites were studied: U66254.1: g.3469T $>\mathrm{C}$ (Hinfl restriction site) and U66254.1: g.1112G $>$ A (TaqI restriction site).

In the examined group the genotype $\mathrm{CC}$ of MYF5 gene was present in $53.8 \%$ of pigs, $42.7 \%$ of pigs had heterozygotic CG genotype and $3.5 \%$ of pigs had GG genotype. CG genotype of $M Y F 5$ was not found in Landrace pigs. Frequency of $M Y F 5$ GG genotype was the lowest and it was detected only in Lithuanian Whites (0.064) and Large Whites (0.100). The highest frequency of CC genotype of MYF5 was found in Landrace (1.000) pig breed.

Some pigs (14.8\%) had AG genotype of LEP TaqI polymorphic site and $85.2 \%$ had GG genotype. CC genotype of LEP Hinfl polymorphic site was found in $45.2 \%$ of pigs, heterozygotic CT genotype in $11.5 \%$ of pigs and TT genotype in $43.3 \%$ of pigs. AG genotype of LEP (TaqI) with the highest frequency was found in the old-type Lithuanian White (0.875). GG genotype of LEP (TaqI) polymorphism with the highest frequency was found in Landrace, Yorkshire $\times$ Large White and Yorkshire $\times$ Pietrain crossbreeds. The highest frequency of CC genotype of LEP (Hinfl) was stated in old-type Lithuanian White (1.000), Large White (1.000) and Yorkshire (1.000), CT genotype - in Yorkshire $\times$ Large White crossbreed (0.375), and TT genotype - in Landrace (0.909). 
Table 2. Miogenic factor 5 (MYF5), leptin (LEP), growth hormone receptor (GHR) and growth hormone (GH) genes allele frequency in different pig breeds and crossbreeds

\begin{tabular}{|c|c|c|c|c|c|c|c|c|c|c|}
\hline \multirow{2}{*}{$\begin{array}{l}\text { Breed/Cross- } \\
\text { breed }\end{array}$} & \multicolumn{2}{|l|}{ MYF5 } & \multicolumn{2}{|c|}{ LEP (Taql) } & \multicolumn{2}{|c|}{ LEP (Hinfl) } & \multicolumn{2}{|l|}{ GHRH } & \multicolumn{2}{|l|}{$\mathrm{GH}$} \\
\hline & $\mathrm{C}$ & G & $A$ & $G$ & $\mathrm{C}$ & $\mathrm{T}$ & C & $A$ & $A$ & G \\
\hline oLiW & 0.650 & 0.350 & 0.438 & 0.563 & 1.000 & 0.000 & 0.333 & 0.667 & 0.611 & 0.389 \\
\hline LiW & 0.734 & 0.266 & 0.075 & 0.925 & 0.300 & 0.700 & 0.229 & 0.771 & 0.329 & 0.671 \\
\hline LW & 0.625 & 0.375 & 0.029 & 0.971 & 1.000 & 0.000 & 0.289 & 0.711 & 0.500 & 0.500 \\
\hline Y & 0.786 & 0.214 & 0.071 & 0.929 & 1.000 & 0.000 & 0.429 & 0.571 & 0.150 & 0.850 \\
\hline $\mathrm{L}$ & 1.000 & 0.000 & 0.000 & 1.000 & 0.091 & 0.909 & 0.227 & 0.773 & 0.364 & 0.636 \\
\hline $\mathrm{LW} \times \mathrm{L}$ & 0.594 & 0.406 & 0.036 & 0.964 & 0.731 & 0.269 & 0.208 & 0.792 & 0.250 & 0.750 \\
\hline$Y \times L W$ & 0.893 & 0.107 & 0.000 & 1.000 & 0.188 & 0.813 & 0.200 & 0.800 & 0.286 & 0.714 \\
\hline$Y \times P$ & 0.909 & 0.091 & 0.000 & 1.000 & 0.278 & 0.722 & 0.300 & 0.700 & 0.300 & 0.700 \\
\hline
\end{tabular}

oLiW - old-type Lithuanian White; LiW - Lithuanian White; LW - Large White; Y - Yorkshire; L - Landrace; P - Pietrain

CC genotype of $G H R H$ was detected in $11 \%$ of pigs, $30 \%$ of pigs had AC genotype and $59 \%$ of pigs AA genotype. Frequency of CC genotype of GHRH varied from 0.091 in Landrace to 0.429 in Yorkshire breed. CC genotype of GHR was not detected in Lithuanian White (old genotype), Large White $\times$ Landraces and Yorkshire $\times$ Large White crossbreeds. AC genotype of $G H R H$ with the highest frequency was found in Lithuanian White (old genotype) (0.667) and was not detected in Yorkshire breed. AA genotype of $G H R H$ with the highest frequency was found in Lithuanian White pigs (0.657).

AA genotype of $G H$ gene, AG genotype and homozygotic GG genotype were found in $11.6 \%$, $47.3 \%$ and $41.1 \%$ of pigs, respectively. The highest frequency of $G H$ gene GG genotype was found in Yorkshire breed (0.700). AA genotype of $G H$ was not found in Yorkshire breed and Yorkshire $\times$ Large White crossbreed but the highest frequency was found in Lithuanian White (old genotype) (0.333) breed. Frequency of $G H$ gene AG genotype varied from 2.000 in Yorkshire $\times$ Pietrain to 0.571 in Yorkshire $\times$ Large White crossbreed.

The comparison of genotypes of each examined gene revealed differences in fattening traits (Table 3 ). The pig age needed to achieve $100 \mathrm{~kg}$ of body weight differed only between $L E P$ (TagI) genotypes and was the lowest in AG genotype. The daily weight gain was influenced by genotype of MYF5, GHRH and $G H$. For $M Y F 5$ the daily weight gain was the highest for CC genotype, for $G H R$ - CC genotype and for $G H$ - AG genotype. FCR was increased in MYF5 GG genotype but for $G H R H$ it was lower for CC and CA genotypes.

The MYF5 genotype did not influence any examined carcass traits. The LEP (TagI) genotype AG was characterized by lower backfat thickness, higher
Table 3. Differences in fattening traits between genotypes

\begin{tabular}{lllll}
\hline $\begin{array}{l}\text { Genetic } \\
\text { factor }\end{array}$ & Genotype $\begin{array}{l}\text { Age to achieve } \\
\text { weight of } 100 \\
\text { kg, day }\end{array}$ & $\begin{array}{l}\text { Daily weight } \\
\text { gain, g }\end{array}$ & $\begin{array}{l}\text { Feed conversion } \\
\text { ratio, kg }\end{array}$ \\
\hline MYF5 & CC & $175.6 \pm 1.30$ & $798.8 \pm 10.84^{\mathrm{a}}$ & $2.66 \pm 0.021^{\mathrm{a}}$ \\
& CG & $176.9 \pm 1.43$ & $751.7 \pm 11.94^{\mathrm{b}}$ & $2.72 \pm 0.023^{\mathrm{a}}$ \\
& GG & $180.5 \pm 4.29$ & $694.1 \pm 35.66^{\mathrm{b}}$ & $2.98 \pm 0.070^{\mathrm{b}}$ \\
LEP & AA & $183.1 \pm 3.10^{\mathrm{a}}$ & $735.3 \pm 27.57$ & $2.71 \pm 0.055$ \\
(Taql) & AG & $175.9 \pm 1.46^{\mathrm{b}}$ & $780.5 \pm 12.97$ & $2.68 \pm 0.026$ \\
LEP & CC & $175.4 \pm 2.02$ & $762.1 \pm 17.14$ & $2.70 \pm 0.035$ \\
(Hinfl) & CT & $173.2 \pm 2.95$ & $792.2 \pm 25.03$ & $2.66 \pm 0.051$ \\
& TT & $174.3 \pm 1.74$ & $798.9 \pm 14.79$ & $2.69 \pm 0.030$ \\
GHRH & CC & $172.7 \pm 3.18$ & $855.9 \pm 25.69^{\mathrm{a}}$ & $2.57 \pm 0.050^{\mathrm{a}}$ \\
& CA & $178.0 \pm 2.10$ & $777.2 \pm 16.99^{\mathrm{b}}$ & $2.64 \pm 0.033^{\mathrm{a}}$ \\
& AA & $176.9 \pm 1.58$ & $770.0 \pm 12.79^{\mathrm{b}}$ & $2.72 \pm 0.025^{\mathrm{b}}$ \\
GH & AA & $180.0 \pm 2.94$ & $770.7 \pm 25.30^{\mathrm{a}}$ & $2.80 \pm 0.048$ \\
& AG & $174.9 \pm 1.67$ & $787.9 \pm 14.39^{\mathrm{b}}$ & $2.64 \pm 0.027$ \\
& GG & $178.2 \pm 1.75$ & $770.8 \pm 15.04^{\mathrm{a}}$ & $2.68 \pm 0.029$ \\
\hline
\end{tabular}

abc - means with different superscripts are significantly different for each gene separately according to Student t-test $(P<0.05)$

meatness content and higher weight of ham in comparison to genotype AA. The LEP (Hinfl) TT genotype had the lowest backfat thickness, and the highest meatness and carcass yield in comparison to genotypes $\mathrm{CC}$ and $\mathrm{CT}$. The carcass yield was also influenced by $G H R H$ genotypes, and it was higher in AA genotype. The GHRH genotypes CC and CA were characterized by higher muscle depth in comparison to AA genotype (Table 4).

After analysis of distribution of alleles, a genetic equilibrium in breeds was determined according to a Hardy-Weinberg principle. In order to evaluate the genetic equilibrium, a $\chi^{2}$ criterion was calculated. There was no statistical difference between actual and theoretical heterozygosity for all examined breeds and crossbreeds (Table 5). 
Table 4. Differences in carcass traits between genotypes

\begin{tabular}{|c|c|c|c|c|c|c|c|c|c|}
\hline $\begin{array}{l}\text { Genetic } \\
\text { factor }\end{array}$ & Genotype & $\begin{array}{l}\text { Average backfat } \\
\text { thickness, } \mathrm{mm}\end{array}$ & $\begin{array}{l}\text { Muscle depth, } \\
\mathrm{mm}\end{array}$ & $\begin{array}{l}\text { Meatness, } \\
\%\end{array}$ & $\begin{array}{l}\text { Carcass } \\
\text { yield, } \%\end{array}$ & $\begin{array}{l}\text { Length } \\
\text { of carcass, } \\
\mathrm{cm}\end{array}$ & $\begin{array}{l}\text { Length } \\
\text { of bacon, } \\
\mathrm{cm}\end{array}$ & $\begin{array}{l}\text { Loin eye area, } \\
\mathrm{cm}^{2}\end{array}$ & $\begin{array}{l}\text { Weight } \\
\text { of ham, } \mathrm{kg}\end{array}$ \\
\hline \multirow[t]{3}{*}{ MYF5 } & $\mathrm{CC}$ & $15.9 \pm 0.435$ & $44.4 \pm 0.853$ & $54.9 \pm 0.436$ & $78.4 \pm 0.23$ & $98.7 \pm 0.23$ & $77.6 \pm 0.24$ & $40.0 \pm 0.47$ & $11.8 \pm 0.040$ \\
\hline & CG & $15.9 \pm$ & 39 & 180 & $6 \pm 0.25$ & $99.1 \pm 0.25$ & $78.2 \pm 0.26$ & .51 & 044 \\
\hline & GG & $15.9 \pm$ & & & & $98.6 \pm 0.75$ & $77.8 \pm 0.77$ & .53 & 133 \\
\hline \multirow{2}{*}{$\begin{array}{l}\text { LEP } \\
\text { (Taql) }\end{array}$} & $\mathrm{AA}$ & $18.2 \pm 0.908^{\mathrm{a}}$ & $43.9 \pm 2.054$ & $52.3 \pm 1.002^{a}$ & $79.2 \pm 0.55$ & $98.8 \pm 0.58$ & $77.6 \pm 0.58$ & $40.9 \pm 1.11$ & $11.6 \pm 0.095^{a}$ \\
\hline & $A G$ & $16.2 \pm 0.471^{\mathrm{b}}$ & $44.5 \pm 0.966$ & $54.6 \pm 0.472^{\mathrm{b}}$ & $78.8 \pm 0.26$ & $99.0 \pm 0.27$ & $77.8 \pm 0.27$ & $39.8 \pm 0.52$ & $11.8 \pm 0.045^{b}$ \\
\hline \multirow{3}{*}{$\begin{array}{l}\text { LEP } \\
\text { (Hinfl) }\end{array}$} & $\mathrm{CC}$ & & & $53.9 \pm 0.678^{a}$ & & $98.6 \pm 0.39$ & $78.0 \pm 0.39$ & & 0.062 \\
\hline & CT & $15.0 \pm$ & & & & $97.7 \pm$ & $77.0=$ & & 091 \\
\hline & TT & $14.7 \pm$ & .136 & $56.2 \pm 0.585^{b}$ & $79.0 \pm 0.30^{b}$ & $98.4 \pm 0.33$ & $77.2 \pm 0.33$ & $40.7 \pm$ & 0.054 \\
\hline \multirow[t]{3}{*}{$\mathrm{GHRH}$} & $\mathrm{CC}$ & & & & & & & & \\
\hline & $\mathrm{CA}$ & & & $55.0 \pm$ & $78.4 \pm 0.33^{\mathrm{a}}$ & $99.1 \pm 0.37$ & $78.3 \pm 0.37$ & & $11.8 \pm 0.058$ \\
\hline & AA & $16.2 \pm 0.487$ & $43.8 \pm 0.975^{b}$ & $54.5 \pm 0.491$ & $79.0 \pm 0.25^{b}$ & $98.8 \pm 0.28$ & $77.7 \pm 0.28$ & $39.9 \pm 0.54$ & $11.8 \pm 0.043$ \\
\hline \multirow[t]{3}{*}{ GH } & AA & & & & & & & & \\
\hline & $A G$ & & & & & & & & $11.7 \pm 0.051$ \\
\hline & GG & $15.4 \pm 0.533$ & $46.6 \pm 1.084$ & $55.5 \pm 0.538$ & $78.9 \pm 0.30$ & $98.7 \pm 0.32$ & $77.6 \pm 0.31$ & $40.0 \pm 0.61$ & $11.8 \pm 0.053$ \\
\hline
\end{tabular}

abc - means with different superscripts are significantly different for each gene separately according to Student t-test $(P<0.05)$

Table 5. Genetic equilibrium evaluation in breeds according to individual gene polymorphism

\begin{tabular}{llll}
\hline $\begin{array}{l}\text { Breed/ } \\
\text { Crossbreed }\end{array}$ & $\begin{array}{l}\text { Actual } \\
\text { heterozygosity }\end{array}$ & $\begin{array}{l}\text { Theoretical } \\
\text { heterozygosity }\end{array}$ & $P$-value \\
\hline oLiW & 0.485 & 0.329 & 0.999 \\
$\mathrm{LiW}$ & 0.297 & 0.334 & 0.311 \\
$\mathrm{LW}$ & 0.307 & 0.292 & 0.98 \\
$\mathrm{Y}$ & 0.217 & 0.258 & 0.579 \\
$\mathrm{~L}$ & 0.152 & 0.178 & 0.769 \\
$\mathrm{LW} \times \mathrm{L}$ & 0.396 & 0.347 & 0.533 \\
$\mathrm{Y} \times \mathrm{LW}$ & 0.296 & 0.236 & 0.999 \\
$\mathrm{Y} \times \mathrm{P}$ & 0.153 & 0.234 & 0.999 \\
\hline
\end{tabular}

oLiW - old-type Lithuanian White; LiW - Lithuanian White; LW - Large White; Y - Yorkshire; L - Landrace; P - Pietrain; P-value was presented as a result of Pearson Chi-Square test

After assessing the effect of genetic factors, it was found that GHRH polymorphism (JX435113.1: g. $405 \mathrm{~A}>\mathrm{C})$ is significant for: daily weight gain (3.6\%; with the highest value for CC genotype); FCR (5.4\%; with lower value for CC and CA genotypes in comparison to AA genotype); muscle depth by $3.6 \%$ (the only gene which influenced this pa-
Table 6. Genetic factors influencing fattening traits

\begin{tabular}{llll}
\hline $\begin{array}{l}\text { Genetic } \\
\text { factors }\end{array}$ & $\begin{array}{l}\text { Age to achieve body } \\
\text { weight of } 100 \mathrm{~kg}, \%\end{array}$ & $\begin{array}{l}\text { Daily weight } \\
\text { gain, } \%\end{array}$ & $\begin{array}{l}\text { Feed conversion } \\
\text { ratio, } \%\end{array}$ \\
\hline MYF5 & 0.3 & $2.8^{*}$ & $7.2^{*}$ \\
LEP (Taql) & $1.4^{*}$ & 0.6 & 0.03 \\
LEP (Hinfl) & 2.1 & 0.1 & 0.4 \\
GHRH & 1 & $3.6^{*}$ & $5.4^{*}$ \\
GH & 0.8 & $3.9^{*}$ & 3.1 \\
Breed & $43.7^{*}$ & $32.1^{*}$ & $18.7^{*}$ \\
\hline
\end{tabular}

${ }^{*}-P<0.05$, according to one-way analysis of variance (ANOVA)

rameter, with higher value for $\mathrm{CC}$ and $\mathrm{CA}$ genotypes in comparison to AA one); carcass yield by $6.8 \%$ (the highest effect from all examined genes; with higher value for CC and CA genotypes in comparison to AA one) (Tables 6 and 7).

LEP (TaqI) polymorphism (U66254.1: g.1112 $\mathrm{G}>\mathrm{A}$ ) is significant for: age to achieve $100 \mathrm{~kg}$ of body weight (1.4\%; with better value stated for AG genotype); backfat thickness (1.3\%; with lower back thickness in AG genotype); meatness (1.5\%; also higher in AG genotype); and weight of ham

Table 7. Influence of genetic factors on carcass traits

\begin{tabular}{lcccccccc}
\hline $\begin{array}{l}\text { Genetic } \\
\text { factors }\end{array}$ & $\begin{array}{l}\text { Average backfat } \\
\text { thickness }\end{array}$ & $\begin{array}{l}\text { Muscle } \\
\text { depth }\end{array}$ & Meatness & $\begin{array}{l}\text { Carcass } \\
\text { yield }\end{array}$ & $\begin{array}{l}\text { Length } \\
\text { of carcass }\end{array}$ & $\begin{array}{l}\text { Length } \\
\text { of bacon }\end{array}$ & $\begin{array}{l}\text { Loin eye } \\
\text { area }\end{array}$ & $\begin{array}{l}\text { Weight } \\
\text { of ham }\end{array}$ \\
\hline MYF5 & 0.1 & 0.7 & 0.1 & 0.3 & 1.4 & 2 & 1.1 & 0.2 \\
LEP (Taql) & $1.3^{*}$ & 0.2 & $1.5^{*}$ & 0.7 & 0.4 & 0.2 & 0.8 & $5.5^{*}$ \\
LEP (Hinfl) & $1.3^{*}$ & 0.9 & $1.8^{*}$ & $3.9^{*}$ & 0.6 & 0.4 & 0.9 & 2 \\
GHRH & 0.8 & $3.6^{*}$ & 0.7 & $6.8^{*}$ & 1.0 & 2.0 & 1.2 & 0.8 \\
GH & 3.2 & 2.6 & 3.1 & $3.8^{*}$ & 0.5 & 0.4 & 1.4 & 2 \\
Breed & $31.8^{*}$ & $27.2^{*}$ & $32.1^{*}$ & 7.7 & $37.1^{*}$ & $17.7^{*}$ & $28.2^{*}$ & $11.1^{*}$ \\
\hline
\end{tabular}

* $-P<0.05$, according to one-way analysis of variance (ANOVA) 
(5.5\% - the only polymorphism which influenced this parameter; also with higher values in AG genotype) (Tables 6 and 7).

LEP (Hinfl) polymorphism (U66254.1: g.3469 $\mathrm{T}>\mathrm{C})$ is significant for: backfat thickness $(1.3 \%$; with the lowest value for TT genotype in comparison to $\mathrm{CC}$ and $\mathrm{CT}$ ones); meatness $(1.8 \%$; with the highest value for TT genotype in comparison to CC and $\mathrm{CT}$ ones); and carcass yield (3.9\%; with higher value for TT genotype in comparison to $\mathrm{CC}$ and $\mathrm{CT}$ ones) (Table 7).

MYF5 polymorphism (Y17154.1: g2200G $>$ C) is statistically significant for fattening traits such as: daily weight gain (2.8\%; the lowest in CC genotype) and FCR $(7.2 \%$; the highest effect from all examined genes, which was stated to be the highest in GG genotype) (Table 6).

The GH polymorphism (M17704.1: g.316G $>$ A) is significant for daily weigh gain $(3.9 \%$; with the highest value for AG genotype) (Table 6).

Breed had a statistically significant effect on all indicators (Tables 6 and 7).

\section{Discussion}

The results of our study on the LEP gene (Hinfl) were different from those obtained by other researchers. For instance, Urban and Mikolašava (2006) found $\mathrm{T}$ allele in 0.867 frequencies $(0.835$ in Large White, 0.946 in Landrace and 0.625 in Duroc pig breeds), and that CC genotype is present only in $2.4 \%$ of livestock. Also Křenková et al. (1999) indicated that the $\mathrm{T}$ allele occurred at high frequency and CC genotype was not found in the Large White, Landrace and Pietrain crossbreed pig populations.

Stępień-Poleszak et al. (2009) found in their study the correlation between $L E P$ gene polymorphism (Hinfl) and fattening and carcass trait. In the investigated synthetic pig line 990 (including Hampshire, Duroc, Polish Large White and various lines of Landrace) two LEP alleles (C and T) and two of the three possible genotypes (TC and TT) were identified. Observed frequency of $\mathrm{T}$ allele was 0.94 and of $\mathrm{C}$ allele -0.06 . Most of the gilts had TT genotype (0.88) and the frequency of heterozygotes was 0.12 .

Kulig et al. (2001) in their study on Polish Landrace pig analysed differences between particular $L E P$ genotypes connected with polymorphism in the Hinfl restriction site (U66254.1: g.3469T >C) associated with fattening and carcass value. They found that an animal with CC genotype has higher daily weight gain in comparison with homozygous
TT. Also, Blicharski et al. (2004) in the study on Polish White pigs found the highest daily body weight gains in animals with $\mathrm{CC}$ genotype in the same polymorphism. Daily gain was associated with fat content, so animals with CC genotype had the highest daily gain and fat content. Whereas, Kennes et al. (2001) obtained other results - in that study animals with TT genotype (HinfI restriction site) grew faster. In the present study $L E P$ polymorphism (U66254.1: g.3469T $>$ C) influenced backfat thickness, meatness and carcass yield.

GH gene may be potential candidate marker for marker assisted selection programmes. Several $G H$ gene polymorphic sites had been reported and the effects of some sites on growth performance were investigated. Song et al. (2003) found pig breed differences in 506 bp fragment of $G H$. Pierzchała et al. (2004) found $G H$ (MspI restriction site) and GH (HaeII restriction site) genotypes significantly related to the weight of ham, weight of ham meat and ham content of carcass. Knorr et al. (1997) demonstrated significant association of $G H$ genotypes (polymorphism: M17704.1: g.316G $>$ A) with eight carcass fatness traits. Wang et al. (2003) showed an association of $G H$ gene polymorphism ( $A p a \mathrm{I}$ restriction site) with carcass meat content in Yorkshire pigs. In the present study, daily body weight gain was influenced by $G H$ polymorphism (M17704.1: g.316G $>A$ ) with the highest value in the CC genotype pigs.

After investigation of $G H R H$ polymorphism, C allele with 0.260 frequency and A allele with 0.740 were found. Franco et al. (2005) noted that pigs with CC genotype had the smallest backfat thickness and the best fattening properties. In the present study very similar results were obtained. Pig with CC genotype with the polymorphism JX435113.1: g. $405 \mathrm{~A}>\mathrm{C}$ had the highest daily weight gain, whereas $\mathrm{CC}$ and CA genotypes pigs had lower FCR, and higher muscle depth and carcass yield in comparison to AA genotype.

Urbański et al. (2006) reported that porcine MYOD1 and MYF5 genes may be useful for selection aiming to improve the value of traits characterizing carcass meat deposition. Statistical analysis of MYF5 (Hinfl polymorphic site) did not show any difference between $\mathrm{CC}$ and GG genotypes and weight of birth, slaughter weight, growing rate (te Pas et al., 1999). The results of our study suggest that pig MYF5 gene influence fattening properties more than carcass traits. CC genotype pigs had the highest daily weight gain but lower FCR only in comparison to GG genotype. 


\section{Conclusions}

The analysis of polymorphisms of the examined genes [miogenic factor 5 (MYF5), leptin (LEP), growth hormone releasing hormone $(G H R H)$ and growth hormone $(G H)$ ] showed that animals with TT genotype of LEP (U66254.1: g.3469T >C) hadbetter carcass traits and those with CC genotype of GHRH (JX435113.1: g.405A $>$ C) had better fattening traits. Moreover the most desirable TT genotype of $L E P$ (U66254.1: g.3469T>C) had the highest frequency in Landrace pig breed and the CC genotype of GHRH (JX435113.1: g.405A >C) - in Yorkshire pig breed. From all examined genes $L E P$ and $G H R H$ genes polymorphisms seem to be the most preferable biomarkers of pig selection process.

\section{References}

Blicharski T., Kurył J., Pierzchała M., 2004. Relationship between polymorphism at loci colipase and leptin and most important fattening and slaughter traits in pigs with special reference to intramuscular fat - a review (in Polish). Pr. Mater. Zootech. Zesz. Spec. 15, 41-46

Caraballo C., Muñoz M., Rodríguez C., Silió L., García-Casco J.M., 2018. Racial verification of Iberian ham and shoulders commercialized in Spanish supermarkets. Arch. Zootec. 68 (Supp. 1), 5-8, ref. 7

Chikuni K., Tanabe R., Muroya S., Fukumoto Y., Ozawa S., 1997. A simple method for genotyping the bovine growth hormone gene. Anim. Genet. 28, 230-232, https://doi.org/10.1111/ j.1365-2052.1997.00095.x

Curi R.A., de Oliveira H.N., Silveira A.C., Lopes C.R., 2005. Effects of polymorphic microsatellites in the regulatory region of IGF1 and GHR on growth and carcass traits in beef cattle. Anim. Genet. 36, 58-62, https://doi.org/10.1111/j.13652052.2004.01226.x

De Oliveira Peixoto J., Facioni Guimarães S.E, Sávio Lopes P., Menck Soares M.A., Vieira Pires A., Gualberto Barbosa M.V., De Almeida Torres R., De Almeida e Silva M., 2006. Associations of leptin gene polymorphisms with production traits in pigs. J. Anim. Breed. Genet. 123, 378-383, https://doi.org/10.1111/ j.1439-0388.2006.00611.x

Franco M.M., Antunes R.C., Silva H.D., Goulart L.H., 2005. Association of PIT1, GH and GHRH polymorphisms with performance and carcass traits in Landrace pigs. J. Appl. Genet. 46, 195-200

Georgescu S.E., Manea M.A., Dinescu S., Costache M., 2014. Comparative study of leptin and leptin receptor gene expression in different swine breeds. Genet. Mol. Res. 13, 7140-7148, https://doi.org/10.4238/2014.February.14.15

Grochowska R., Zwierzchowski L., Snochowski M., Reklewski Z., 1999. Stimulated growth hormone $(\mathrm{GH})$ release in Friesian cattle with respect to GH genotypes. Reprod. Nutr. Dev. 39, 171-180, https://doi.org/10.1051/rnd:19990202

Jiang Z.-H., Gibson J.P., 1999. Genetic polymorphisms in the leptin gene and their association with fatness in four pig breeds. Mamm. Genome 10, 191-193, https://doi.org/10.1007/ s003359900968
Kennes Y.M., Murphy B.D., Pothier F., Palin M.-F., 2001. Characterization of swine leptin (LEP) polymorphisms and their association with production traits. Anim. Genet. 32, 215-218, https:// doi.org/10.1046/j.1365-2052.2001.00768.x

Kim J., Chung H., Kim S., Park H., Kewon D.-H., 2009. Discovery of single nucleotide polymorphisms in FABP3 and leptin gene in pig. Arch. Anim. Breed. 52, 106-107, https://doi.org/10.5194/ aab-52-106-2009

Knorr C., Moser G., Müller E., Geldermann H., 1997. Associations of $\mathrm{GH}$ gene variants with performance traits in $F_{2}$ generations of European wild boar, Piétrain and Meishan pigs. Anim. Genet. 28, 124-128, https://doi.org/10.1111/j.13652052.1997.00093.x

Křenková L., Kuciel J., Urban T., 1999. Association of the RYR1, GH, LEP and TF genes with carcass and meat quality traits in pigs. Czech J. Anim. Sci. 44, 481-486

Kulig H., Grzesiak W., Szatkowska I., 2001. Effect of leptin gene polymorphism on growth and carcass traits in pigs. Arch. Anim. Breed. 2001. 44, 291-296, https://doi.org/10.5194/aab-44291-2001

Lee T., Shin D.-H., Cho S., Kang H.S., Kim S.H., Lee H.-K., Kim H., Seo K.-S., 2014. Genome-wide association study of integrated meat quality-related traits of Duroc pig breed. AsianAustralas. J. Anim. Sci. 27, 303-309, https://doi.org/10.5713/ ajas.2013.13385

Li J., Ran X.-Q., Wang J.F., 2006. Identification and function of the growth hormone gene in Rongjiang pig of China. Acta Physiol. Sinica 58, 217-224

Pierzchała M., Blicharski T., Kurył J., 2003. Growth rate and carcass quality in pigs as related to genotype at loci POU1F1/ Rsal (Pit1/Rsal) and GHRH/Alul. Anim. Sci. Pap. Rep. 21, 159-166

Pierzchała M., Blicharski T., Kurył J., 2004. Growth rate and carcass quality in relation to GHIMspl and GH/Haell PCR-RFLP polymorphism in pigs. Anim. Sci. Pap. Rep. 22, 57-64

Rejduch B., 2008. Genes associated with production and health in farm animals. J. Cent. European Agric. 9, 829-836

Song C.Y., Gao B., Jing R.B., Tao Y., Mao J.D., 2003. Study on pig growth hormone gene polymorphisms in western meat-type breeds and Chinese local breeds. J. Zhejiang Univ. Sci. 4, 734-739, https://doi.org/10.1631/jzus.2003.0734

Stępień-Poleszak D., Pietruszka A., Kawęcka M., 2009. Effect of leptin gene polymorphism on fattening and slaughter value of Line 990 gilts. Acta Vet. Brno 78, 267-272, https://doi. org/10.2754/avb200978020267

te Pas M.FW., Soumillion A., Harders F.L., Verburg F., van den Bosch T.J., Galesloot P., Meuwissen T.H.E., 1999. Influences of myogenin genotypes on birth weight, growth rate, carcass weight, backfat thickness, and lean weight of pigs. J. Anim. Sci. 77, 2352-2356, https://doi.org/10.2527/1999.7792352x

Urban T., Mikolášová R., 2006. Genetic variability in the leptin receptor and heart fatty acid binding protein genes in pigs. Acta Fytotechn. Zootechn. 9, 29-31

Urbański P., Pierzchała M., Kamyczek M., Różycki M., Kurył J., 2006. Relations between the polymorphism in the coding and 5 '-flanking regions of the porcine MYOD1 and MYF5 genes and productive traits in pigs. J. Anim. Feed Sci. 15, 225-235, https://doi.org/10.22358/jafs/66895/2006

Wang W., Huang L., Gao J., Ding J., Chen K., Ren J., Luo M., 2003. Polymorphism of growth hormone gene in 12 pig breeds and its relationship with pig growth and carcass traits. AsianAustralas. J. Anim. Sci. 16, 161-164, https://doi.org/10.5713/ ajas.2003.161 
Wang W., Xue W., Zhou X., Zhang L., Wu J., Qu L., Jin B., Zhang X., Ma F., Xu X., 2012. Effects of candidate genes' polymorphisms on meat quality traits in pigs. Acta Agric. Scand. A Anim. Sci. 62, 120-126, https://doi.org/10.1080/09064702.2 013.765907
Zhu C., Gi G., Tao Z., Song C., Zhu W., Song W, Li H., 2014. Development of skeletal muscle and expression of myogenic regulatory factors during embryonic development in Jinding ducks (Anas platyrhynchos domestica). Poult. Sci. 93, 1211-1216, https://doi.org/10.3382/ps.2013-03695 